ISSN:1308-8173

Geliş Tarihi: 10.01.2020
E-ISSN: 1308-8505

Kabul Tarihi: 07.07.2021
YIL: 2021

Online Yayın: 02.08.2021
Cilt: 36 Sayı: 1 Sayfa: 1-12

Doi: 10.24988/ije.202136101

ÖZGÜN ARAŞTIRMA

\title{
Üniversite Öğrencilerinin Küresel İklim Değişikliğine Yönelik Görüşlerinin Araştırılması: Bir Yapısal Eşitlik Model Önerisi Veysel YILMAZ ${ }^{1}$, Pınar Ay Gökçe GÜLEÇ² \\ Özet
}

Günümüzün hararetli tartışmalarından birisi küresel iklim değișikliği ve küresel ısınmadır (KíKI). KÍKI'nın sonucunda meydana gelen; kuraklık, sel felaketleri, şiddetli kasırgalar, buzulların erimesi gibi etkenler sonucunda bitkiler, hayvanlar ve insan toplulukları ciddi risk altındadır. Bu çalışmada; Eskişehir Osmangazi Üniversitesi'nde öğrenim gören 400 öğrencinin KIKI hakkındaki bilgilerinin, çevre öncelikli davranışlara etkisini araştırmak amacıyla bir model önerilmiştir. Önerilen modelde yer alan değiş̧kenler arasındaki iliş̧kiler ve modelin uyumu yapısal eșitlik modellemesi (YEM) yardımıyla araştırılmıştır. Çalışma sonucunda KíKI'ya ilişskin bilgi puanındaki bir birimlik artışın farkındalıkta 0,84 birimlik; farkındalıktaki bir birimlik artış ise risk algısında 0,54 birimlik bir artışa yol açacağı ortaya çıkmıştır.

Anahtar kelimeler: Küresel İklim Değişikliği, Küresel Isınma, Tutumların Ölçülmesi, Yapısal Eşitlik Modellemesi Jel Kodu: $C 12, C 40, C 80$

Investigation of University Students' Views on Global Climate Change: A Proposal of The Structural Equation Model

\section{Abstract}

One of today's strong discussions is global climate change and global warming (GCGW). As a result of GCGW; plants, animals and human communities are at serious risk because of factors such as drought, flood disasters, rise in ocean and sea levels, severe hurricanes, melting of glaciers. In this study, a model has been proposed to investigate the effect of 400 university students' knowledge studying at Eskişehir Osmangazi University about GCGW on pro-environmental behaviors. The relationships between the variables in the proposed model and the fit of the model have been investigated by using structural equation modeling (SEM). According to the result of the study, regarding GCGW; that one unit increase in the knowledge score will lead to increase of 0.84 units in the awareness level, and one unit increase in awareness level will lead to increase of 0.54 units in the risk perception.

Keywords: Global Climate Change, Global Warming, Measurement of Attitudes, Structural Equation Modeling Jel Codes: $C 12, C 40, C 80$

\section{GíRIŞ}

Küresel ısınma; karbondioksit, metan gazı, azot peroksit, ozon ve kloroflorokarbon gibi sera gazlarının atmosferde yoğun bir biçimde artması sonucunda yery"üzüne yakın atmosfer tabakaları ile yeryüzü sıcaklığının yapay olarak artması sürecidir. Başka bir deyișle küresel ısınma; bütün dünyada sıcaklığın sistematik bir şekilde artması sürecidir. Küresel ısınmaya bağlı olarak diğer iklim öğelerinin de (yağıș, nem, hava hareketleri, kuraklık vb.) değişmesi olayı küresel iklim değişikliği olarak tanımlanmaktadır (Çepel, 2003; Aydın, 2017).

İklim değişikliği, tüm dünyada dikkatleri üzerine çeken, etkileri ve alınabilecek önlemler için gündemde öne çlkmaya devam eden küresel boyutta yaşanılan bir sorun olarak karşımıza çımmaktadır. Birleşmiş Milletler İklim Değişikliği Çerçeve Sözleşmesi'nde iklim değişikliği, "karşılaştırılabilir bir zaman döneminde gözlenen doğal iklim değişikliğine ek olarak, doğrudan ya da dolaylı küresel atmosferin bileşimini bozan insan etkinlikleri

ATIF ÖNERísi (APA): Yılmaz, V. Güleç, P. A. G. (2021). Üniversite Öğrencilerinin Küresel İklim Değişikliğine Yönelik Görüsslerinin Araștırılması: Bir Yapısal Eșitlik Model Önerisi. İzmir İktisat Dergisi, 36(1), 1-12. Doi:10.24988/ije.202136101

${ }^{1}$ Prof. Dr., Eskişehir Osmangazi Üniversitesi, Fen Edebiyat Fakültesi, Eskişehir. vyilmaz@ogu.edu.tr ORCID: 0000-0001-5147-5047

${ }^{2}$ Yüksek Lisans Öğrencisi, Eskişehir Osmangazi Üniversitesi, Fen Edebiyat Fakültesi, Eskişehir. paggulec@ gmail.com ORCID: 0000-0003-2737-7919 
sonucunda iklimde oluşan bir değişiklik" biçiminde tanımlanmaktadır (cevreonline.com, 2019). İklim bilimcilerin görüşleri, atmosferdeki sera gazı emisyonlarındaki artıştan kaynaklanan küresel ısınma olacağı ve dolayısıyla iklim değişikliği gerçekleşeceği yönündedir. Meydana gelecek iklim değişikliklerinin; tarımsal faaliyetlerde, bitki ve hayvanların yaşam alanlarında değişikliklere yol açacağı öngörülmektedir.

Dünyada son yıllarda küresel ısınma nedeni ile yaşanan çevre felaketleri insanları tedirgin etmekte ve bunlarla ilgili önlemler alınmaktadır. Çevreye karşı duyarlı bireyler yetiştirmek bu anlamda büyük önem taşımaktadır.

Literatür incelendiğinde küresel iklim değişikliği ve küresel ısınma (KİKI) ile ilgili; farkındalık, bilgi, risk algısı, tutum ve çevre öncelikli davranış kavramları arasında anlamlı ilişkiler olduğu görülmüştür. Türkiye gibi gelişmekte olan ülkelerde öğrencilerin kavram yanılgıları ve bilgi düzeylerinin ortaya konması önemli olup, bu çalışmada elde edilen veriler ile üniversite öğrencilerinin KİKI'ya ilişkin bilgi, farkındalık, risk algısı ve tutumlarının çevre öncelikli davranışları üzerindeki etkisi araştırılmıştır.

\section{LITERATÜR TARAMASI}

Kellstedt vd. (2008), KİKI risklerini belirlemede bilgi ve kişisel etkinliğin rolünü araştırmıştır. Çalışmada, Texas A\&M Üniversitesi'ndeki bilim adamları tarafından; demografik bilgilerin ve KİKI hakkında risk beklentisi, politik ideoloji, algılanan etkinlik gibi ifadelerin yer aldığı bir anket tasarlanmıștır. Anket, 13 Temmuz-10 Ağustos 2004 tarihleri arasında Amerika Birleşik Devletleri'nde rastgele seçilen 1903 kişiye telefon yoluyla anket uygulanmıștır. Elde edilen verilere faktör analizi uygulanmıştır. Çalışmanın sonucunda, KİKI'yla ilgili daha yüksek bilgi düzeyine sahip ve bilim adamlarına güven duyan katılımcıların KİKI hakkında daha az endişe duydukları ve kendilerini daha az sorumlu hissettikleri görülmüştür.
Whitmarsh (2009), KIKI hakkında bireylerin görüşlerini incelemek için çevresel kaygl, KİKI'ya ilişkin farkındalık, tutum ve davranışları içeren sekiz sayfalık bir anket geliştirmiştir. Örneklem olarak, Portsmouth (İngiltere'nin güney sahilindeki bir şehir) ve çevresinde yaşayan 1771 kişi tabakalı örnekleme yöntemiyle seçilmiştir. Posta yolu ile dağıtılan anketlerden 589 adeti geri dönmüştür. Geri gönderilen anketlerin 277'si (yüzde 47) "iklim değişikliği" anketi ve 312 (yüzde 53) küresel ısınma anketidir. Niteliksel araştırma verileri; NVivo'ya aktarılmış ve hiyerarşik kodlama prosedürü kullanılarak kodlanmıştır. Bulgular, halkın "iklim değişikliği" anlayışı ile "küresel ısınma" anlayışı arasında önemli niteliksel ve niceliksel farklılıklar olduğunu göstermektedir. Katılımcıların yüzde 17,6'sı "küresel ısınmayı" dergilerden duyduklarını söylerken, "iklim değişikliği” için bu durum yüzde 19,9'a çıkmıştır. Ayrıca, küresel ısınmanın iklim değișikliğine göre daha fazla endișe uyandırdığı tespit edilmiştir.

Visschers vd. (2010), nükleer enerji santrallerinin kabulünde algılanan iklim değişikliği faydaları, risk algısı ve algılanan enerji arzı faydalarını incelemişlerdir. Visschers vd. (2010), çalışmalarında İsviçre'deki kota örneklemesi yoluyla seçtikleri çeşitli yaş gruplarından 1222 kişiye telefon yoluyla uyguladıkları anket sonuçlarını kullanmışlardır. Çalışmada nükleer enerji santrali kabulü, risk algısı, iklim değişikliğinin azaltılmasına yönelik fayda algısı, güvenli bir enerji arzı için algı, etki ve güven gibi yapıların yer aldığı bir YEM önerilmiştir. Sonuçlar, nükleer enerji santrallerine karşı risk algısının düşük olduğunu ve iklim değişikliğini azaltmaya yönelik algılanan faydanın düşük olduğunu göstermektedir.

Spence vd. (2010), çevre ile ilgilenen insanların, iklim değişikliği ve nükleer enerji riskleri hakkındaki endişeleri, çevresel endişenin iklim değișikliği endișesi ile fosil yakıtlar ve yenilenebilir enerji kaynakları arasındaki ilişkide benzer bir etkiye sahip olup olmadığı 
araştırılmıştır. İklim değişikliği konusundaki kaygıların fosil yakıtlara verilen destek ile negatif, yenilenebilir enerji kaynaklarına verilen destek ile ise pozitif olarak ilișkili olacağı düşünülmektedir. Çalışmalarında İngiliz ulusunun görüșlerini içeren Ipsos-MORI şirketinin kota örneklemesi ile seçtikleri 15 yaş ve üstü 1491 kişiye uyguladıkları anket sonuçlarını kullanmışlardır. Anket iklim değişikliği ve enerji kaynaklarıyla ilgili çeşitli sorunları ve algıları ölçen 139 maddeden oluşmuştur. Katılımcılar ile 1 Ekim - 6 Kasım 2005 tarihleri arasında İngiltere, Galler ve İskoçya'daki 257 örnekleme noktasında kendi evlerinde görüşülmüștür. Ankette, farklı enerji kaynaklarının değerlendirilmesi, iklim değişikliği algıları, çevre kaygıları ve nükleer enerji kullanımı ile iklim değişikliğini azaltma arasındaki ilişkiye dair ifadeler yer almaktadır. Elde edilen verilerin analizinde $t$ testi ve ANOVA kullanılmıştır. İklim değișimi ve çevreye ilişkin kaygı duymanın, nükleer enerji ve yenilenebilir enerjiye ilişkin algl faktörlerini nasıl etkilediğini gösterebilmek için üç farklı YEM önerilmiştir. Çalışmada katılımcıların çevresel ve iklim değişikliğine ilişkin kaygllarının, yenilenebilir enerji kaynaklarına bakış açısını olumlu, nükleer enerji kaynaklarına bakış açısını ise olumsuz bir şekilde etkilediği belirlenmiştir. Bunlara ek olarak, nükleer enerjinin iklim değişikliğini azalttığına inanan katılımcıların çevresel kaygılarının daha düşük olduğu görülmüştür.

Güven ve Aydoğdu (2012), öğretmen adaylarının çevre sorunlarına yönelik farkındalık düzeylerini belirleyebilmek için güvenilir ve geçerli bir farkındalık ölçeği geliştirmiştir. Araştırmada tarama modeli kullanılmıştır. Örneklem olarak 2009-2010 Eğitim-Öğretim yılında Fen Bilgisi Öğretmenliği Anabilim Dalı'nda 4. sınıfta öğrenim gören 203 öğretmen adayı ve 3. sınıfta öğrenim gören 93 öğretmen adayı ele alınmıştır. Çalışmada, güvenirliği sağlanan çevre sorunlarına yönelik 44 maddelik farkındalık ölçeği geliştirilmiştir. Hazırlanan ölçek Fen Bilgisi öğretmen adaylarına uygulanmıştır. Çalışmanın sonucunda çevresel farkındalık düzeylerinin ölçekte yer alan maddelere göre değişiklik gösterdiği ve farkındalıkların beklenenin altında olduğu görülmüştür.

Aydın (2014), ortaöğretim öğrencilerinin küresel ısınma konusundaki bilgi düzeylerinin ve yanlış kavramalarının belirlenmesini amaçlamıştır. Çalışmada; daha önce küresel ısınma bilgi seviyesini ölçmeye yönelik geliştirilen bir anket uygulanmış ve örneklem olarak Karabük il merkezindeki liselerde öğrenim gören 592 öğrenci seçilmiştir. Verilerin analizinde $t$ testi ve tek yönlü varyans analizi kullanılmıştır. Çalışmanın sonucunda; öğrencilerin küresel ısınma konularındaki bilgi düzeylerinin cinsiyete göre farklılık göstermezken, okul ve sinıflara göre farklılık gösterdiği görülmüştür. Ayrıca, tüm örneklem ele alındığında ise küresel ısınma konusundaki bilgi düzeylerinin ortalamanın üstünde olduğu tespit edilmiştir.

Stevenson vd. (2014), küresel iklim değişikliğine ilişkin geliştirdikleri anketi MartMayıs 2013 tarihleri arasında Kuzey Carolina, Amerika Birleşik Devletleri'nde öğrenim gören 287 ortaokul öğrencisine yüz yüze uygulamışlardır. Bu çalışmada; iklim değişikliği bilgisinin risk algısına etkisinde antropojenik (insanların sebep olduğu) küresel ısınma kabulünün aracılık etkisi incelenmiştir. Araştırma hipotezleri YEM kullanılarak test edilmiştir. Çalışmadan antropojenik küresel ısınma kabulünün aracılık etkisi tespit edilmiştir.

Arbuckle vd. (2015), küresel iklim değişikliğine ilişkin yaptıkları çalışmada verileri "2011 Iowa Çiftlik ve Kırsal Yaşam Anketi” aracılı̆̆ıyla toplamıştır. Posta yoluyla 2030 çiftçiye gönderilen anketten 1276 adeti analiz için uygun bulunmuştur. Çalışmada değişkenler arası ilişkiler için iki model önerilmiştir. $\mathrm{Bu}$ modeller, tarımsal ve çevresel çıkarlara olan güveni, iklim değişikliği yaşandığı inancını, iklim değişikliği risk algısını ve iklim değişikliğini azaltmaya yönelik destek değişkenleri arasındaki ilişkileri içermektedir. Çalışmanın sonucunda; iklim değişikliğinin yaşandığı inancının, tarımsal risk algısını 
pozitif yönde etkilediği görülmüștür. Ayrıca, iklim değişikliğinin meydana geldiği ve insan faaliyetlerinden kaynaklandığı inancının, azaltma politikasına destek üzerinde doğrudan ve olumlu bir etkiye sahip olduğu görülmüștür.

Koçer ve Delice (2016), yeşil reklamlara yönelik tutumların çevresel duyarlılığı etkileyip etkilemediğini ortaya koymak ve bu etki üzerinde çevresel kaygı faktörünün aracılık rolünü araştırmıştır. Araştırmada farklı yaş gruplarındaki 360 kişiden yüz yüze anket yöntemiyle veriler toplanmıștır. Ankette demografik bilgilerin yer aldığı sorular ile birlikte, 5'li likert ölçeğiyle oluşturulmuş biri yeşil reklamlarla ilgili diğeri çevresel duyarlılık ve çevresel kaygı ile ilgili iki farklı ölçeğe yer verilmiştir. Araştırma sonucuna göre, çevresel duyarlılıkla yeşil reklamlara yönelik olumlu tutumlar arasında aynı yönlü bir ilişki olduğu belirlenmiştir. Aynı zamanda, yeşil reklamlara yönelik olumlu tutumların çevresel duyarlılığı etkilediği ve yeşil reklamlara yönelik tutumlar ile çevresel duyarlılık arasındaki ilişkide çevresel kaygının aracılık rolü olduğu tespit edilmiştir.

$\mathrm{Hu}$ vd. (2017), bireylerin politik ideolojisi ile iklim değişikliği risk algısı arasındaki ilişkiyi ve bu ilişkinin iklim değişikliği bilgisinden etkilenip etkilenmediğini araştırmıştır. Çalışmada, demografik bilgilerin yer aldığı ve politik ideoloji, iklim değişikliği risk algısı ve iklim değişikliği bilgisi gibi ifadeleri içeren bir anket tasarlanmıştır. Örneklem olarak çeşitli yaş gruplarından 520 katılımcı seçilmiştir. Verilerin analizi için çoklu regresyon modeli kullanılmıştır. Çalışmanın sonucunda daha yüksek düzeydeki iklim değişikliği bilgisinin; politik ideoloji ve liberalizm ile iklim değişikliği risk algısı arasındaki pozitif ilişkiyi azalttığ tespit edilmiştir.

Aydın (2017)'ın yaptığı çalışmada, üniversite öğrencilerinin küresel ısınma hakkındaki bilgi düzeylerinin belirlenmesi amaçlanmıştır. Yapılan araştırma tarama modeli özelliği taşımaktadır. Araştırmaya 2016-2017 akademik yılının bahar döneminde, Karabük Üniversitesi Edebiyat Fakültesi'nde öğrenim gören son sınıf öğrencilerinden 472 kişi katılmıştır. Elde edilen verilerin analizinde $t$ testi ve tek yönlü varyans analizi kullanılmıştır. Çalışma sonucunda küresel ısınmaya ilişkin öğrencilerin bilgi düzeylerinin ortalamanın üzerinde olduğu ancak yine de ciddi bilgi eksiklikleri olduğu görülmüştür.

Durkaya ve Durkaya (2018), Bartın Üniversitesi öğrencilerinin küresel ısınma farkındalık seviyesini belirlenmeye çalışmıştır. Tabakalı örnekleme yöntemiyle rastgele seçilen 536 üniversite öğrencisine anket uygulanmıștır. Gruplar arasında anlamlı bir farkın olup olmadığını belirlemek amacıyla kikare analizi kullanılmıștır. Öğrencilerinin \%86'sının küresel ısınma kavramını bildiği ve bu oranın kadınlarda erkeklere göre daha iyi olduğu görülmüștür. Ayrıca, küresel ısınma konusunda eğitim alan öğrencilerin, eğitim almayanlara göre daha bilinçli olduğunu tespit edilmiştir.

Choon vd. (2018); çevre bilinci, sosyal güven ve çevre bilgisinin, iklim değişikliği azaltma davranışları ve yeşil faaliyetlere katılım üzerindeki etkisi ve bu etkide risk algının aracılık rolü araştırmıştır. Çalışmada, demografik bilgilerin yer aldığı, risk beklentisi, sosyal güven, risk bilinci ve çevresel tutum gibi bölümlerden oluşan bir anket tasarlanmıştır. Örneklem olarak Malezya, Klang Vadisi'ndeki çeşitli yaş gruplarından 210 katılımcı seçilmiştir. Klang Vadisi'nde yaşayan katılımcılara iklim değişikliği gibi çevresel konularda farkında olup olmadıkları ve çevreye etkilerini azaltmaya yönelik yaptıkları eylemler sorulmuştur. Elde edilen verilere faktör analizi uygulanmış ve bir YEM önerilmiştir. Ayrıca, risk algısının aracılık rolü araştırılmıştır. Bulgulara göre, çevre bilinci ve sosyal güven ile risk algısı arasında anlamlı bir ilişki olduğu görülmüş ancak, çevre bilgisi ile risk algısı arasında anlamlı bir ilişki belirlenememiştir. Bunlara ek olarak; risk algısının iklim değişikliğini azaltma davranışları ve yeşil faaliyetlere katılım üzerindeki önerilen aracılık etkisi desteklenmemiştir. 
Dong vd. (2018), küresel iklim değişikliğine ilişkin geliştirdikleri anketi Amerika Birleşik Devleti'nde 1023 katılımcıya uygulamışlardır. Çalışmada ele alınan modelde bağımlı değișken iklim değişikliği bilgisi iken bağımsız değişken iklim davranışı (iklim değişikliğini azaltmaya yönelik davranış) olarak ele alınmıștır. Çalışmanın sonucunda, iklim değişikliği bilgisi ile iklim değişikliğini azaltmaya yönelik davranışlar arasında risk algısının aracılık etkisi tespit edilmiştir. Ayrıca bu çalışmada medya ve kurumlar gibi bilgi sağlayıcılarına olan güvenin, iklim değişikliğini azaltmaya yönelik eylemleri pozitif yönde etkilediği görülmüştür. Sonuçlar, iklim değişikliği hakkında yüksek bilgiye sahip bireylerin risk algısının daha fazla olduğunu, bu nedenle hem iklim değişikliğini azaltmaya yönelik davranıșta bulunduklarını hem de daha fazla iklim değişikliği önlemi aldığını göstermiştir.

Ayrıntılı olarak taranan literatürden, küresel ısınma ve küresel iklim değişikliği kavramlarının birçok araştırmacı tarafından çalışıldığı ve araştırmalarda YEM kullanıldığı, ayrıca aracılık etkisinin araştırıldığı görülmüștür. $\mathrm{Bu}$ çalışmada ise, Eskișehir Osmangazi Üniversitesi'nde öğrenim gören üniversite öğrencilerinin $(n=400)$ KİKI'ya ilişkin bilgi, farkındalık, risk algısı ve tutumlarının çevre öncelikli davranışları üzerindeki etkisi araştırılmıştır.

\section{YÖNTEM}

\subsection{Araştırmanın Amacı}

Çalışmada, KİKI'ya ilişkin çevre duyarlılığının geliştirilebilmesinde bilgi, farkındalık, risk algısı, tutum gibi faktörlerinin etkili olabileceği varsayılmıştır. KİKI'ya ilişkin bilgi düzeyi, farkındalık, risk algısı ve tutumun çevre öncelikli davranışa etkisini ve aynı zamanda bu değișkenlerin birbirleri ile ilişkilerini araştırmak için bir YEM önermek ve modelin uygunluğu çeşitli uyum ölçüleri dikkate alınarak sınanması çalışmanın amacını oluşturmaktadır.

\section{2 Örneklem}

Çalışmanın verileri Kasım/Aralık-2018'de Eskişehir Osmangazi Üniversitesi'ndeki Fen Edebiyat Fakültesi İstatistik Bölümü ve Ziraat Fakültesi Ziraat Mühendisliği Bölümü öğrencilerine yüz yüze anket çalışması gerçekleştirilerek derlenmiştir. Araştırmanın örneklemi $n=400$ katılımcıdan oluşmuştur. Üniversite öğrencilerinin yüzde 46,5'i kadın, yüzde 53,5'i erkektir. Fakülte/Bölüm göz önünde bulundurulduğunda, İstatistik Bölümü ve Ziraat Mühendisliği Bölümü katılımcı sayısı birbirine eşittir. Katılımcıların yüzde 5,8'i 1. sinıf, yüzde 27'si 2. sinıf, yüzde 32,8'i 3. sınıf ve yüzde 34,5'i 4. sinıf öğrencisidir. Hazırlık, 5. sınıf ve 6. Sinıfta öğrenim gören öğrenci bulunmamaktadır. Öğrencilerin annelerinin yüzde 1,5'i okuma-yazma bilmiyorken, yüzde 33'ü ilkokul, yüzde 22,8'i ortaokul, yüzde 30,8'i lise, yüzde 12'si ise üniversite mezunudur. Babalarının ise; yüzde $0,5^{\prime} \mathrm{i}$ okuma-yazma bilmiyorken, yüzde 21,8'i ilkokul, yüzde 20'si ortaokul, yüzde 37,3'ü lise, yüzde 20,5'i üniversite mezunudur. Gelir durumları incelendiğinde; öğrencilerin yüzde 6,5'i "Çok düşük", yüzde 14,3'ü "Düşük", yüzde 50,3'ü “Orta”, yüzde 25,8'i “İyi”, yüzde 3,3'ü ise “Çok iyi" olarak nitelendirmektedir.

\subsection{Veri Toplama Aracı}

KİKI'yı etkileyen faktörler ve bu faktörlerin birbirleriyle ilişkisini araștırmak üzere; Choon vd. (2018), Masud vd. (2015), Hu vd. (2017), Afacan ve Demirci (2011), Aydın (2014) ve Aydın (2017) çalışmalarından yararlanarak bir anket geliștirilmiştir. Ankette yer alan 18. soru Aydın (2014); 19., 20., 23., 24., 27., 28., ve 32. sorular Masud vd. (2015); 21. soru Aydın (2017); 29. soru Hu vd. (2017); 30., 31. ve 34. sorular Choon vd. (2018); 36. soru Afacan ve Demirci (2011) çalışmalarından yararlanarak geliştirilmiştir.

Anketin ilk bölümünde katılımcıların demografik bilgileri yer alırken, ikinci bölümünde KIKKI'ya yönelik bilgiyi ölçen sorular, üçüncü bölümde KİKI'ya ilişkin bilgi, KİKI'ya ilişkin farkındalık, KIKKI'ya ilişkin risk algısı, KİKI'ya karşı tutum ve dördüncü 
bölümde ise çevre öncelikli davranış olmak üzere 6 faktör ele alınmış olup toplamda 37 ifade yer almaktadır. Anket formu tasarlandıktan sonra Fen Edebiyat Fakültesi İstatistik Bölümü'nden 140 öğrenci ile pilot çalışma yapılmış ve Cronbach Alfa (CA) değeri 0,878 olarak hesaplanmıştır.

Üniversite öğrencilerinin KIKI'ya ilișkin bilgilerinin varlığının araştırılması için; ankette ikinci bölümdeki ifadelere yer verilmiş olup, bu ifadelerin "Doğru", "Yanlış", "Bilgim Yok" şeklinde yanıtlanması istenmiştir. Verilen cevaplar neticesinde KİKI'ya ilişkin doğru bilgisi olanlara 1 puan, yanlış bilgisi olanlara ve bilgisi olmayanlara 0 puan verilerek ve bu puanlar toplanarak bilgi puanı faktörü elde edilmiştir.

KİKI'ya ilişkin bilgi, farkındalık, risk algısı ve tutum ifadelerinin ölçülmesinde 10'lu likert ölçeği kullanılmıștır (1-Hiç Katılmıyorum; 10Tamamen Katılıyorum). Benzer şekilde; çevre öncelikli davranış ifadelerinin ölçülmesinde de 10'lu likert ölçeği kullanılmıștır (1-Hiçbir Zaman; 10-Her zaman). Ölçme aracl; KÍKI'ya ilişkin 10 ifadenin yer aldığı bilgi puan (bilgipua), 3 ifadenin yer aldığı bilgi (bilgi), 3 ifadenin yer aldığı farkındalık (fark), 3 ifadenin yer aldığı risk (risk), 3 ifadenin yer aldığı tutum (tut) ve 2 ifadenin yer aldığı davranış (dav) maddelerinden oluşmaktadır.

\subsection{Araştırma Modeli ve Hipotezlerin Tasarımı}

Araştırmada sınanacak hipotezlerin şema haline getirilmiş modeli Şekil 1'de gösterilmiştir. Bu model, Choon vd. (2018), Masud vd. (2015), Hu vd. (2017) ve Kellstedt vd. (2008) çalışmalarından yararlanarak önerilmiştir.

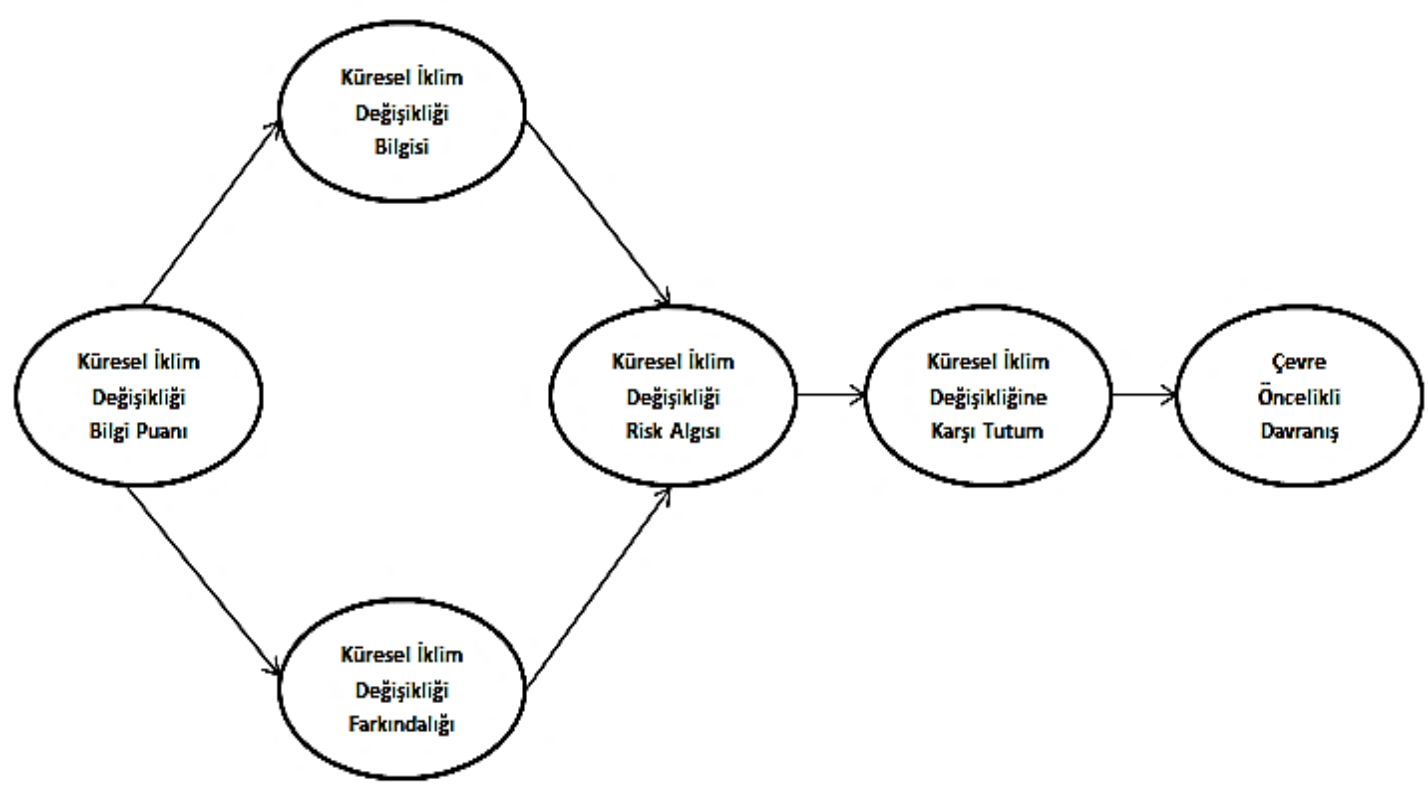

Şekil 1:KİKI Araştırma Modeli

Şekil.1'de verilen modele göre bireylerin KİKI ile ilgili bilgi ve farkındalık düzeylerinin artmasıyla KİKI'ya ilişkin risk algısının artacağı, bunların sonucunda tutum ve davranışlarının etkileneceği varsayımı ile modele ilişkin hipotezler kurulmuştur.

H1: KİKI’ya ilişkin; bilgi puanı, bilgiyi pozitif ve anlamlı olarak etkiler.

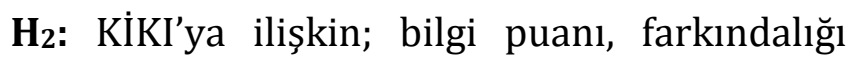
pozitif ve anlamlı olarak etkiler.

H3: KİKI'ya ilişkin; bilgi, riski pozitif ve anlamlı olarak etkiler.

H4: KİKI'ya ilişkin; farkındalık, riski pozitif ve anlamlı olarak etkiler. 
H5: KiKI'ya ilişkin; risk, tutumu pozitif ve anlamlı olarak etkiler.

H6: KIKI'ya ilişkin; tutum, çevre öncelikli davranışı pozitif ve anlamlı olarak etkiler.

Araştırma modelinin uyumu ve hipotezlerin sınanmasında YEM kullanılmıştır. YEM'e iliş̧in analiz sonuçlarının değerlendirilmesi için kullanılan ilk uyum indeksi ki-kare $\left(\chi^{2}\right)^{\prime}$ dir. Bagozzi ve Heatherton'e (1994) göre; $\chi^{2}$ gözlenen kovaryans matrisi ile kestirilen kovaryans matrisi arasındaki farkın anlamlılığını test etmektedir (İlhan ve Çetin, 2014). $\chi^{2}$ değerinin anlamlı olmaması gözlenen kovaryans matrisi ile kestirilen kovaryans matrisi arasında anlamlı fark bulunmadığını ve dolayısıyla modelin uyumlu olduğu gösterir. $\chi^{2}$ değeri örneklem büyüklüğüne oldukça duyarlı olduğundan model uyumunu değerlendirirken, $\chi^{2}$ değerinden hareket etmek yerine; $\chi^{2}$ değerinin serbestlik derecesine bölünmesiyle elde edilen değerin esas alınması önerilmektedir (İlhan ve Çetin, 2014).

YEM değerlendirilmesinde kullanılan indekslerin en çok kullanılanları iyilik uyum indeksi (GFI), düzeltilmiş iyilik uyum indeksi (AGFI), normalleștirilmiș uyum indeksi (NFI), bağıl uyum indeksi (RFI), artmalı uyum indeksi (IFI) ve karşılaştırmalı uyum indeksi (CFI)'dir. 0 ile 1 arasında değișen tüm bu indekslerde model için elde edilen değerin 0,90'ı aşması model ile veriler arasında iyi bir uyum olduğunun göstergesidir (Kelloway, 1998; Yücenur vd., 2011).

Yaklaşık hatalarının ortalama karekökü (RMSEA) ana kütledeki yaklaşık uyumun bir ölçümüdür. RMSEA değerinin 0,05 'den küçük ya da eşit olması iyi bir uyumu; 0,05 ve 0,08 arasında olması yeterli uyumu; 0,08 ve 0,10 arasinda olması ise vasat uyumu göstermektedir (Çelik ve Yılmaz, 2013, s. 33).

Standartlaştırılmış hata kareleri ortalamasının karekökü (SRMR) kareli hataları temel alan bir ölçüdür. SRMR indeksinin değeri; 0,05 değerinden küçük olduğunda iyi bir uyumun, 0,10'dan küçük olduğunda ise kabul edilebilir bir uyumun olduğuna işaret etmektedir (Çelik ve Yllmaz, 2013, s. 34). Siralanan uyum indekslerine ilișkin mükemmel ve kabul edilebilir uyum ölçütleri Tablo 1'de sunulmuştur.

Tablo 1: Modelin Uyumunun Değerlendirilmesi

\begin{tabular}{lll}
\hline $\begin{array}{l}\text { Uyum } \\
\text { Ölçüleri }\end{array}$ & \multicolumn{1}{c}{ İyi Uyum } & Kabul Edilebilir Uyum \\
\hline GFI & $0,95 \leq \mathrm{GFI} \leq 1,00$ & $0,90 \leq \mathrm{GFI} \leq 0,95$ \\
AGFI & $0,90 \leq \mathrm{AGFI} \leq 1,00$ & $0,85 \leq \mathrm{AGFI} \leq 0,90$ \\
NFI & $0,95 \leq \mathrm{NFI} \leq 1,00$ & $0,90 \leq \mathrm{NFI} \leq 0,95$ \\
NNFI & $0,97 \leq \mathrm{NNFI} \leq 1,00$ & $0,95 \leq \mathrm{NNFI} \leq 0,97$ \\
CFI & $0,97 \leq \mathrm{CFI} \leq 1,00$ & $0,95 \leq \mathrm{CFI} \leq 0,97$ \\
SRMR & $0 \leq \mathrm{SRMR} \leq 0,05$ & $0,05 \leq \mathrm{SRMR} \leq 0,10$ \\
IFI & $0,95 \leq \mathrm{IFI} \leq 1,00$ & $0,90 \leq \mathrm{IFI} \leq 0,95$ \\
RFI & $0,95 \leq \mathrm{RFI} \leq 1,00$ & $0,90 \leq \mathrm{RFI} \leq 0,95$ \\
RMSEA & $0<\mathrm{RMSEA}<0,05$ & $0,05<\mathrm{RMSEA}<0,10$ \\
$\chi^{2} / s . d$. & $0 \leq \chi^{2} / s . d . \leq 2$ & $2 \leq \chi^{2} / s . d . \leq 3$ \\
\hline
\end{tabular}

\subsection{YEM'e İlişkin Analiz Sonuçları}

Veri analizinde LISREL 8.80 paket programı kullanılmıştır. Araştırma modeli için uyum iyiliği indeksleri, $\quad \chi^{2}=178,18 ; \quad s d=84$; $\chi^{2} / s d=2,121 ; \quad$ RMSEA $=0,053 ; \quad$ NFI $=0,97$; NNFI=0,98; CFI $=0,99 ;$ SRMR $=0,046 ; \mathrm{GFI}=0,94$; AGFI= 0,92; olarak hesaplanmıştır. Araştırma modeli; GFI ve $\chi^{2} / s d$ değeri bakımından kabul edilebilir uyum limitleri arasında iken, diğer değer bakımından mükemmel uyum göstermektedir.

Bilgi faktörünü (bilgi) ölçmek bil18, bil19, bil20; farkındalık faktörünü (fark) ölçmek için fark21, fark23, fark24; risk faktörünü (risk) ölçmek için risk27, risk28, risk 29; tutum faktörünü (tut) ölçmek için tut30, tut31, tut32; çevre öncelikli davranış faktörünü (dav) ölçmek için ise dav34 ve dav36 ifadeleri kullanılmıștır. Araștırma modelinin LISREL ile analizi sonucu elde edilen path diyagramı Şekil 2'de verilmiştir.

YEM analizi sonucu bulunan yapısal eşitlikler;

\begin{tabular}{ll}
\hline bilgi $=0.89$ bilgipua +0.21 & $\mathrm{R}^{2}=0.79$ \\
fark $=0.84$ bilgipua +0.29 & $\mathrm{R}^{2}=0.71$ \\
risk $=0.30$ bilgi +0.54 fark +0.38 & $\mathrm{R}^{2}=0.62 \quad$ (3) \\
tut $=0.65$ risk +0.58 & $\mathrm{R}^{2}=0.42$ \\
dav $=0.41$ tut +0.83 & $\mathrm{R}^{2}=0.17$
\end{tabular}




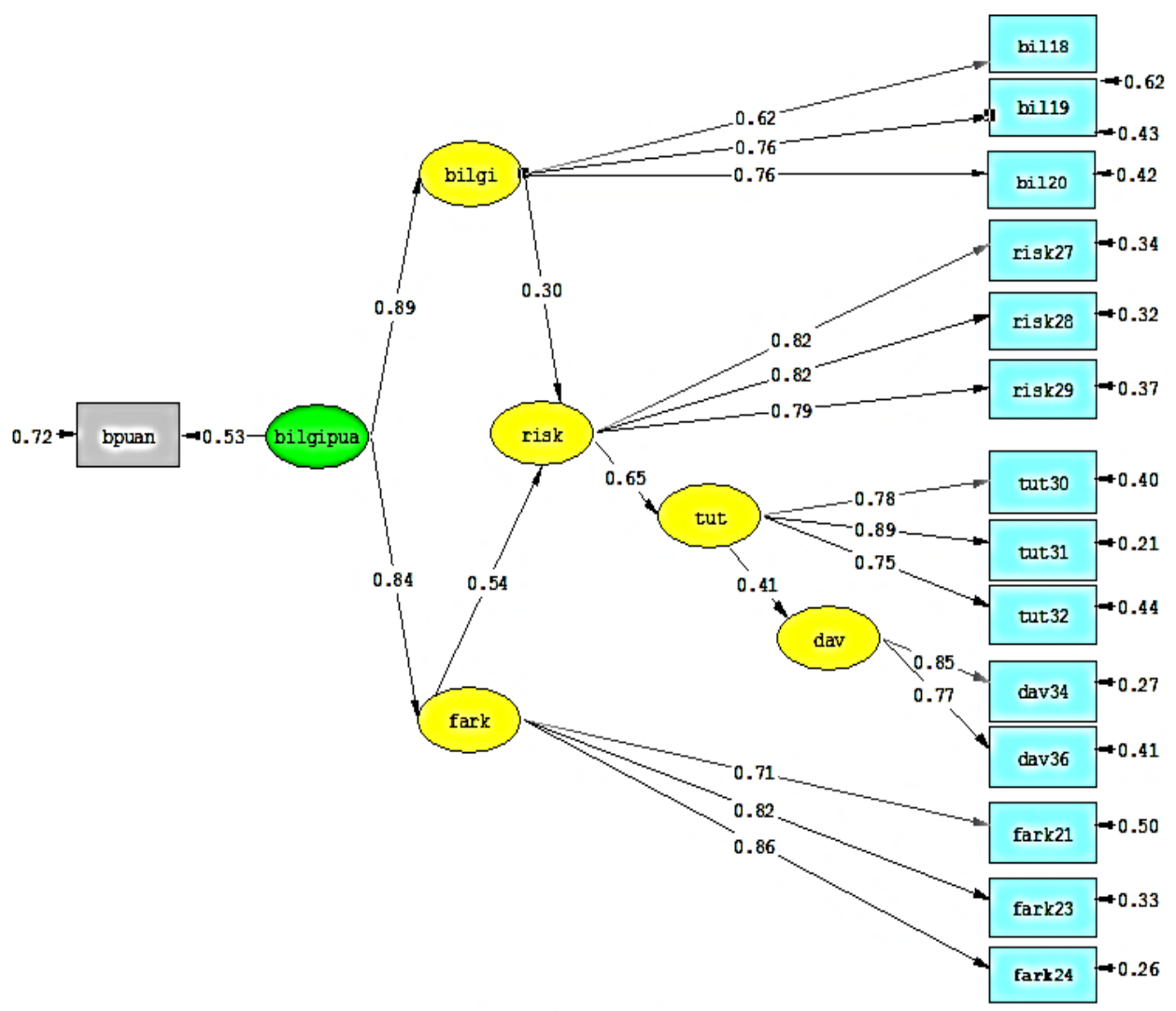

Chi-Square $=178.18, \mathrm{df}=84, \mathrm{P}$-value $=0.00000, \mathrm{RMSEA}=0.053$

Şekil 2: Modele İlişkin Path Diyagramı

KİKI'ya ilişkin; Eşitlik 1'den bilgideki değişimin \%79'unun bilgi puanı ile açıllanabildiği, Eşitlik 2'den farkındalıktaki değișimin \%71'inin bilgi puanı düzeyi ile açılklanabildiği, Eşitlik 3'ten risk algısındaki değişimin \%62'sinin bilgi ve farkındalık düzeyi ile açıklanabildiği, Eşitlik 4 'ten tutumdaki değişimin $\% 42$ 'sinin risk algısı seviyesi ile açıklanabildiği, Eşitlik 5 'ten çevre öncelikli davranıştaki değişimin \%17'sinin tutum ile açıklanabildiği söylenebilir. Anket soruları yardımıyla insan duygu ve düşünceleri gibi soyut ifadelerin ölçülmeye çalışıldığı araştırmalarda $\mathrm{R}^{2}$ değeri genellikle 1'e yakın çıkması beklenemez. $\mathrm{Bu}$ nedenle $\mathrm{R}^{2}$ değerlerinin \%17'ye kadar düşmesi olağan değerlendirilebilir.

Modele ilișkin parametre tahminleri incelendiğinde; regresyon analizlerinde yapılanlara benzer yorumlar getirilebilir. KIKI'ya iliş̧in; bilgi puanı düzeyindeki bir birimlik artış/azalışın bilgi düzeyinde 0,89 birim artış/azalışa yol açacağı, bilgi puanı düzeyindeki bir birimlik artış/azalışıın farkındalık düzeyinde 0,84 birim artış/azalıșa yol açacağı, farkındalık sabitken bilgi düzeyindeki bir birimlik artış/azalışın risk algısında 0,30 birim artış/azalışa yol açacağı, bilgi sabitken farkındalık düzeyindeki bir birimlik artış/azalışın risk algısında 0,54 birim artış/azalışa yol açacağı, risk algısındaki bir birimlik artış/azalışın tutum düzeyinde 0,65 birim artış/azalışa yol açacağı ve tutumdaki bir birimlik artış/azalışın, davranıșta 0,41 birimlik artış/azalışa yol açacağı söylenebilir. Tablo 2'de; modelde yer alan gizil değişkenler arasındaki ilişkiler için hesaplanan standartlaştırılmış parametreler, bu parametrelerin anlamlılıklarının sınanmasında kullanılan $\mathrm{t}$ istatistikleri ve hipotez test sonuçları verilmiștir. t değerleri incelendiğinde hepsinin istatistiksel olarak anlamlı olduğu $(|t|>2,58 ; p<0,01)$ görülmektedir. Buradan 
önerilen hipotezlerin kabul edildiği anlaşılmaktadır.

Tablo 2: Standartlaştırılmış Parametre Tahminleri, t- Değerleri ve Hipotezler

\begin{tabular}{lllll}
\hline Hipotezler & Akış Yönü & $\begin{array}{l}\text { Standartlaştırılmış } \\
\text { Parametrelerin Tahmini } \\
\text { Değerleri }\end{array}$ & $\begin{array}{l}\text { t- } \\
\text { Değeri }\end{array}$ & Sonuç \\
\hline $\mathrm{H}_{1}$ & bilgipua $\rightarrow$ bilgi & 0,89 & 10,22 & Desteklendi \\
$\mathrm{H}_{2}$ & bilgipua $\rightarrow$ fark & 0,84 & 11,43 & Desteklendi \\
$\mathrm{H}_{3}$ & bilgi $\rightarrow$ risk & 0,30 & 3,54 & Desteklendi \\
$\mathrm{H}_{4}$ & fark $\rightarrow$ risk & 0,54 & 6,27 & Desteklendi \\
$\mathrm{H}_{5}$ & risk $\rightarrow$ tut & 0,65 & 10,93 & Desteklendi \\
$\mathrm{H}_{6}$ & tut $\rightarrow$ dav & 0,41 & 6,67 & Desteklendi \\
\hline
\end{tabular}

Tablo 3: Faktörlere Ait Standart Yükler, t-Değerleri ve $\mathrm{R}^{2}$ Değerleri

\begin{tabular}{|c|c|c|c|c|}
\hline Faktörler & Maddeler & $\begin{array}{l}\text { Standart } \\
\text { Yükler }\end{array}$ & $\begin{array}{l}t- \\
\text { Değeri }\end{array}$ & $R^{2}$ \\
\hline $\begin{array}{l}\text { Bilgi (bilgi) } \\
\mathrm{CA}=0,755 \\
\mathrm{CR}=0,76 \\
\mathrm{AVE}=0,51\end{array}$ & $\begin{array}{l}\text { bil18: KIKI sonucunda buzulların erimesiyle akarsu, göl ve } \\
\text { deniz seviyeleri yükselecektir. } \\
\text { bil19: Sera gazlarındaki hızlı artışlar Türkiye'de KiKI'ya } \\
\text { neden olur. } \\
\text { bil20: Karbondioksit emisyonu Türkiye'deki KíKI'nın başlıca } \\
\text { nedenlerinden biridir. }\end{array}$ & $\begin{array}{l}0,62 \\
0,76\end{array}$ & $\begin{array}{l}11,17 \\
11,23\end{array}$ & $\begin{array}{l}0,57 \\
0,58\end{array}$ \\
\hline $\begin{array}{l}\text { Farkindalık } \\
\text { (fark) } \\
\text { CA }=0,831 \\
\text { CR }=0,84 \\
\text { AVE }=0,64\end{array}$ & $\begin{array}{l}\text { fark21: Türkiye'de KíKI'nın etkilerinin yaşandığının } \\
\text { farkındayım. } \\
\text { fark23: KiKI'nın insan hayatını etkilediğinin farkındayım. } \\
\text { fark24: KíKI'nın Türkiye'deki doğal çevreyi etkilediğinin } \\
\text { farkındayım. }\end{array}$ & $\begin{array}{l}0,71 \\
0,82 \\
0,86\end{array}$ & $\begin{array}{l}14,96 \\
15,46\end{array}$ & $\begin{array}{l}0,67 \\
0,74\end{array}$ \\
\hline $\begin{array}{l}\text { Risk (risk) } \\
\text { CA }=0,854 \\
\text { CR }=0,85 \\
\text { AVE }=0,66 \\
\end{array}$ & $\begin{array}{l}\text { risk27: KíKI insanların yaşam standardını düşürecektir. } \\
\text { risk28: KíKI nedeniyle tarımsal üretim risk altındadır. } \\
\text { risk29: KíKI, ailemin yaşadı̆ıı çevre üzerinde olumsuz etkiler } \\
\text { yaratacaktır. }\end{array}$ & $\begin{array}{l}0,82 \\
0,82 \\
0,79\end{array}$ & $\begin{array}{l}17,81 \\
17,01\end{array}$ & $\begin{array}{l}0,66 \\
0,68 \\
0,63\end{array}$ \\
\hline $\begin{array}{l}\text { Tutum (tut) } \\
\text { CA }=0,84 \\
\text { CR }=0,82 \\
\text { AVE }=0,60\end{array}$ & $\begin{array}{l}\text { tut30: KİKI ile mücadeleye yönelik tutumlarımı ve } \\
\text { davranışlarımı değiştirmek benim etik sorumluluğumdur. } \\
\text { tut31: KiKI konusunda bir şeyler yapmayı ahlaki bir görev } \\
\text { olarak hissediyorum. } \\
\text { tut32: Komşularımı KiKI'yı azaltmaya yönelik davranışlarda } \\
\text { bulunmaya yöneltmek benim sorumluluğumdur. }\end{array}$ & $\begin{array}{l}0,78 \\
0,89 \\
0,75\end{array}$ & $\begin{array}{l}17,15 \\
15,08\end{array}$ & $\begin{array}{l}0,60 \\
0,79 \\
0,56\end{array}$ \\
\hline $\begin{array}{l}\text { Davranış (dav) } \\
\text { CA }=0,792 \\
\text { CR }=0,79 \\
\text { AVE }=0,66\end{array}$ & $\begin{array}{l}\text { dav34: Ev ürünlerimi/gereçlerimi satın alırken diğerlerine } \\
\text { göre daha pahalı da olsa çevre dostu olanları tercih ederim. } \\
\text { dav36: Kissisel bakım ürünleri satın alırken diğerlerine göre } \\
\text { daha pahalı da olsa içeriğinin doğa dostu olmasına dikkat } \\
\text { ederim. }\end{array}$ & 0,85 & 7,45 & 0,59 \\
\hline
\end{tabular}




\subsection{Modelin Geçerliliği}

Modelin geçerliliğinin sağlanabilmesi için üç koşul sağlanmalıdır. İlk olarak, her bir gözlenen gizil değişkene iliş̧in standart yüklerinin 0,50'den büyük ve istatistiksel olarak anlaml olması gerekmektedir (Fornell ve Larcker, 1981). Modelin geçerliliğinin sağlanabilmesi için üç koşul sağlanmalıdır. İlk olarak, her bir gözlenen gizil değişkene ilişkin standart yüklerinin 0,50 'den büyük ve istatistiksel olarak anlamlı olması gerekmektedir (Fornell ve Larcker, 1981). 0-1 arasında değerler alan standart yüklerin 1'e yaklaşması; ifadeler ve ifadelerin ait olduğu faktörler arasında ilişkinin yüksek olduğu anlamına gelir. İkinci olarak, faktörlere ilişkin Yapı Güvenilirliği (CR) ve Cronbach Alfa (CA) değerleri 0,70'den büyük olmalıdır (Hair vd., 1998). 0-1 arasında değerler alan CA değerinin 1'e yaklaşması güvenirliliğin yüksek olduğunu gösterir. Son olarak, faktörlere ilişkin Ortalama Açlklanan Varyans (AVE) değerleri 0,50'den büyük olması gerekmektedir (Fornell ve Larcker, 1981).

Tablo 3'te YEM analizinden elde edilen standart yükler, bu yüklerin anlamlılık testinde kullanılan $\mathrm{t}$ istatistikleri, ilgili faktörü açıklama yüzdeleri olan $\mathrm{R}^{2}$ değerleri, $\mathrm{CR}, \mathrm{CA}$ ve $\mathrm{AVE}$ değerleri verilmiştir. Standart yükler incelendiğinde, yüklerin 0,62-0,89 arasında olduğu görülmektedir. Ayrıca, standart yüklere ilişkin $\mathrm{t}$ değerleri incelendiğinde, istatistiksel olarak anlamlı olduğu $(|\mathrm{t}|>2,58 ; \mathrm{p}<0,01)$ anlaşılmaktadır. Çalışmada faktörlere ilişskin Cronbach Alfa değerleri 0,76-0,85 arasında olduğundan faktörlerin güvenilir şekilde ölçüldüğü değerlendirilebilir. Bunlara ek olarak CR değerleri incelendiğinde 0,70 'den büyük oldukları görülmektedir. Bu nedenle yapıların yakınsaklık geçerliliği sağlandığ değerlendirebilir. Faktörlere ilişkin AVE değerlerinin ise 0,50 'den büyük oldukları görülmektedir. Tablo 3'te yer alan değerler sonucunda modelin güvenirliği ve geçerliliğinin sağlandığı anlaşılmaktadır.

\section{SONUÇ}

YEM, nedensel ilişkilerin tahmin edilmesinde ve test edilmesinde kullanılan, bir teori geliştirme ve test etme yaklaşımıdır. $\mathrm{Bu}$ çalışmada, üniversite öğrencilerinin KİKI hakkındaki bilgilerinin çevre öncelikli davranışta bulunmalarına etkisi araştırılmıştır. $\mathrm{Bu}$ amaçla, KİKI'yı etkileyen faktörler araștırılmış ve literatürden yararlanarak bir YEM önerilmiştir. Önerilen model, çeşitli uyum iyiliği ölçütleri göz önüne alınarak değerlendirilmiş ve modelin iyi uyuma sahip olduğu görülmüştür. Model hipotezleri hakkında 6 hipotez desteklenmiştir. Neden sonuç ilişkisi arasında en yüksek katsayının bilgi puan ve farkındalık değişkenleri arasında olduğu görülmüştür.

Masud vd. (2015) çalışmalarında KİKI hakkındaki bilgi, farkındalık, risk algısı ve tutumun çevre öncelikli davranışlar üzerindeki etkisi araştırılmıștır. Araștırma modelinde yer alan faktörlere ilişkin CA değerleri bilgi için 0,83 ; farkındalık için 0,816; risk algısı için 0,82; tutum için 0,80 ve davranış için 0,81 şeklindedir. Bu çalışmada ise; faktörlere ilişkin CA değerlerinin bilgi için 0,755; farkındalık için 0,831; risk algısı için 0,854; tutum için 0,84 ve davranış için 0,792 olduğu tespit edilmiştir. Bunlara ek olarak; Masud vd. (2015) çalışmalarında, değişkenler arasındaki ilişkiyi gösteren katsayının risk ve tutum için 0,301 $(\mathrm{p}<0.01)$; tutum ve davranış için $0,421(\mathrm{p}<0.01)$ olduğu görülmüştür. Bu çalışmada ise; risk ve tutum değişkenleri arasındaki katsayı 0,65; tutum ve davranış değişkenleri arasındaki katsayı 0,41 olarak tespit edilmiştir. Masud vd. (2015) çalışmaları ile karşılaştırıldığında; farkındalık, risk algısı ve tutum faktörlerinin güvenilirliklerinin daha yüksek olduğu, risk ve tutum değişkenleri arasında ilişkiyi gösteren katsayının daha yüksek olduğu değerlendirilebilir.

Çalışmada öğrencilerin ankette yer alan ifadelere verdikleri yanıtların ortalamalarının fakültelere ve cinsiyete göre farklılık gösterip göstermediği araştırılmıştır. Örneklem olarak ele alınan İstatistik ve Ziraat Mühendisliği Bölümü öğrencilerinin verdikleri yanıtlar incelendiğinde; Ziraat Mühendisliği Bölümü öğrencilerinin KİKI hakkında daha fazla bilgi 
sahibi oldukları, farkındalık ve risk algılarının daha yüksek olduğu, daha güçlü tutum sergiledikleri ve daha fazla çevre öncelikli davranışta bulundukları ve dolayısıyla çevreye önem verdikleri görülmektedir. Cinsiyete göre incelendiğinde, kadınların ve erkeklerin KIKI'ya ilișkin bilgi ve farkındalıklarının aynı düzeyde olduğu ancak, kadınların risk algısının daha yüksek olduğu, daha güçlü tutum sergiledikleri ve daha çok çevre öncelikli davranıșta bulundukları görülmektedir.

$\mathrm{Bu}$ çalışmanın; karar vericilere, duyarlılık politikalarını ve stratejilerini teşvik etmede yardımcı olacağı, iklim değişikliği ile ilgili kamu bilinci oluşturup, artan çevre bilgisinin, çevreye karşı olan tutumları da olumlu etkileyeceği düşünülmektedir. Araştırmanın sadece Eskișehir Osmangazi Üniversitesi öğrencilerine yapılmış olması araştırmanın önemli bir kısıtıdır. Bu nedenle diğer üniversitelerdeki öğrencilere yapılacak araștırmalarda değişik sonuçlara ulaşılabilir. Araștırmanın diğer bir kısıtı İstatistik ve Ziraat Mühendisliği Bölümü öğrencilerine yapılmış olmasıdır. Diğer fakültelerde bulunan öğrencilere yapılacak araștırmalardan elde edilecek sonuçlar, bu çalışmada ulaşılan sonuçların açıklayıcılı̆̆ı açısından önem taşımaktadır.

Küresel ısınma konusuna örgün eğitim ve yaygın eğitimde öğrencilerin seviyelerine uygun bir şekilde yer verilmesi kavram yanılgılarının önüne geçmek için de önem arz etmektedir. Ayrıca öğrencilerin çevreye duyarlılık düzeylerinin saptanarak, duyarlılıklarının daha yüksek seviyelere ulaşması için eğitim ve öğretim faaliyetlerinde yeni yaklaşımlar benimsenmesini ve teorik anlamda yapılan çalışmaların daha ileriye götürülmesini sağlamak çalışmanın en büyük amacıdır.

\section{KAYNAKÇA}

Afacan, Ö., Güler, M. P. D. (2011). Sürdürülebilir çevre eğitimi kapsamında tutum ölçeği geliştirme çalışması, 2nd International Conference on New Trends in Education and Their Implications, 904-913.

http://cevreonline.com/iklim-degisikliginedir/, erişim tarihi: 12.05.2019.

Arbuckle, J. G., Morton, L. W., Hobbs, J. (2015), Understanding farmer perspectives on climate change adaptation and mitigation: The roles of trust in sources of climate information, climate change beliefs, and perceived risk, Environment and Behavior, 47(2), 205-234.

Aydın, F., 2017, Üniversite öğrencilerinin küresel ısınma hakkındaki bilgi düzeylerinin belirlenmesi, Journal of Social Scienes and Humanities, 1 (1), 118-132.

Aydın, F., (2014). Ortaöğretim öğrencilerinin küresel ısınma konusundaki bilgi düzeylerinin belirlenmesi, Turkish Journal of Education, 3(4), 15-27.
Choon, S. W., Ong, H., B., Tan, S., H. (2018). Does risk perception limit the climate change mitigation behaviors? Environment, Development and Sustainability, 21 (4), 18911917.

Çelik, H. E. ,Yılmaz, V., (2013). Yapısal eşitlik modellemesi temel kavramlar-uygulamalarprogramlama, Ankara: Anı Yayıncılık.

Dong, Y., Hu, S. , Zhu, J. (2018). From source credibility to risk perception: How and when climate information matters to action, Resources, Conservation and Recycling, 136, 410-417.

Durkaya, B. ,Durkaya, A. (2018). Küresel ısınma farkındalığı Bartın Üniversitesi öğrencileri örneği, Bartın Orman Fakültesi Dergisi, 20(1), 128-144.

Fornell, C. ,Larcker, D. F. (1981) Structural equation models with unobservable variables and measurement error: Algebra and statistics, Journal of Marketing Research, 18(3), 382-388. 
Güven, E., Aydoğdu, M. (2012). Çevre sorunlarına yönelik farkındalık ölçeğinin geliştirilmesi ve öğretmen adaylarının farkındalık düzeylerinin belirlenmesi, Journal of Teacher Education and Educators, 1(2), 185202.

Hair Jr., J. F., Anderson, R. E., Tatham, R. L., Black, W. C. (1998). Multivariate data analysis (5th ed.), Upper Saddle River, NJ: Prentice Hall.

Hu, S., Jia, X., Zhang, X., Zheng, X., Zhu, J. (2017). How political ideology affects climate perception: Moderation effects of time orientation and knowledge, Resources, Conservation and Recycling, 127, 124-131.

İlhan, M. ,Çetin, B. (2014). LISREL ve AMOS programları kullanılarak gerçekleștirilen yapısal eșitlik modeli (YEM) analizlerine ilişkin sonuçların karşılaştırılması, Eğitimde ve Psikolojide Ölçme ve Değerlendirme Dergisi, 5(2), 26-42.

Kellstedt, P. M., Zahran, S. , Vedlitz, A. (2008). Personal efficacy, the information environment, and attitudes toward global warming and climate change in the United States, Risk Analysis, 28(1), 113-126.

Koçer, L. L. ,Delice, T. (2016). Yeşil reklamlara yönelik tutumların çevresel duyarlılığa etkisi: Çevresel kaygının aracılık rolü, Humanities Scienes, 11(2), 112-139.

Masud, M. M., Akhtar, R., Afroz, R., Al-Amin, A. Q., Kari, F. B. (2015). Pro-environmental behavior and public understanding of climate change, Mitigation and Adaptation Strategies for Global Change, 20(4), 591-600.

Spence, A., Poortinga, W., Pidgeon, N., Lorenzoni, I. (2010). Public perceptions of energy choices: The influence of beliefs about climate change and the environment, Energy \& environment, 21(5), 385-407.

Stevenson, K. T., Peterson, M. N., Bondell, H. D., Moore, S. E. , Carrier, S. J. (2014). Overcoming skepticism with education: Interacting influences of worldview and climate change knowledge on perceived climate change risk among adolescents, Climatic Change, 126( 3-4), 293-304.

Tobler, C., Visschers, V. H. , Siegrist, M. (2012). Consumers' knowledge about climate change, Climatic Change, 114(2), 189-209.

Visschers, V. H. M., Keller, C. , Siegrist, M. (2011) Climate change benefits and energy supply benefits as determinants of acceptance of nuclear power stations: Investigating an explanatory model, Energy Policy, 39(6), 36213629.

Whitmarsh, L. ( 2009) .What's in a name? Commonalities and differences in public understanding of "climate change" and "global warming", Public Understanding of Science, 18 (4), 401-420.

Yücenur, G. N., Demirel, N. Ç., Ceylan, C. , Demirel, T. (2011). Hizmet değerinin müşterilerin davranıșsal niyetleri üzerindeki etkisinin yapısal eşitlik modeli ile ölçülmesi, Doğuş Üniversitesi Dergisi, 12(1), 156-168. 